\title{
Leptin induces ROS via NOX5 in healthy and neoplastic mammary epithelial cells
}

\author{
SINDA MAHBOULI ${ }^{1}$, AUDREY DER VARTANIAN $^{1}$, SOPHIE ORTEGA $^{1}$, \\ STÉPHANIE ROUGÉ ${ }^{1}$, MARIE-PAULE VASSON ${ }^{1,2}$ and ADRIEN ROSSARY ${ }^{1}$ \\ ${ }^{1}$ University of Clermont Auvergne, INRA, UNH, Human Nutrition Unit, CRNH Auvergne, F-63000 Clermont-Ferrand; \\ ${ }^{2}$ Clermont-Ferrand University Hospital, Jean-Perrin Center, Nutrition Unit, Clermont-Ferrand, France
}

Received September 13, 2016; Accepted August 1, 2017

DOI: $10.3892 /$ or.2017.6009

\begin{abstract}
NADPH oxidase (NOX) complexes (a family of seven isoforms) drive cellular ROS production in pathological processes such as cancer. NOX-driven ROS production is involved in cell mechanisms from signalling to oxidative stress. Leptin, an adipokine overexpressed in obese patients, has been investigated in studies on breast carcinogenesis, but its effects on oxidative stress remain largely unexplored, especially in breast cancer. The study used three human mammary epithelial cell models presenting different neoplastic status (healthy primary HMECs, neoplastic MCF-7 cells and neoplastic MDA-MB-231 cells) to determine the effects of leptin on short-term ROS production and to characterize the enzymes involved. All three cell models significantly expressed NADPH oxidase isoform 5 (NOX5) in our culture conditions. All models showed induced ROS production regardless of leptin concentration $(10 \mathrm{ng} / \mathrm{ml}$ mimicking good health, $100 \mathrm{ng} / \mathrm{ml}$ mimicking obesity). Cell treatment with either siRNA against NOX5, NOX inhibitor DPI or a calcium channel blocker (verapamil) confirmed the putative involvement of the NOX5 isoenzyme in ROS production. Moreover, cell treatments suppressed ROS production under leptin at both concentrations. Neoplastic cells appeared unable to downregulate NOX5 mRNA expression under leptin. Leptin emerged as a potential activator of ROS production in human epithelial mammary cells, where the ROS production was
\end{abstract}

Correspondence to: Dr Adrien Rossary, Laboratoire de Biochimie, Biologie Moléculaire et Nutrition, Faculté de Pharmacie, 28 place Henri Dunant, 63000 Clermont-Ferrand Cedex 01, France E-mail: adrien.rossary@uca.fr

Abbreviations: ROS, reactive oxygen species; NOX, NADPH oxidase; DUOX, dual oxidases; HMEC, human mammary epithelial cells; NOS, NO synthases; q-PCR, quantitative real-time PCR; $\mathrm{DCF}$, dichlorofluorescein; RFU, relative fluorescence unit; RLU, relative luminescence units; siRNA, small interfering RNA; DPI, diphenyliodonium; ApoC, apocynin; BMI, body mass index

Key words: leptin, ROS production, breast carcinogenesis, NADPH oxidases, NOX5 apparently linked to NOX5 activation. This novel finding could shed light on the potential role of obesity-associated hyperleptinemia in mammary cells via the activation of NOX enzymes.

\section{Introduction}

Excessive ROS production leads to oxidative stress, which is known to contribute to the pathogenesis of several diseases including inflammation (1), diabetes and obesity (2) and to play a role in carcinogenesis $(3,4)$. In physiological conditions, ROS production is involved in many cell functions such as signalling (5), and growth (4). Excluding the mitochondria, cellular ROS production involves two other systems (6). The first is NADPH oxidases (NOX), the main driver of cellular ROS production in physiological (7) and pathological processes (8). The NOX family counts seven NOX isoenzymes, i.e. NOX1 to 5 plus dual oxidases (DUOX)1 and 2, some of which are expressed in cancer cells (9-11). The second ROS-producing system in cells are the NO synthases (NOS) $(12,13)$. Three NOS isoenzymes are differentiated on tissue expression patterns $(12,14,15)$. NO production plays a role in cell signalling (14), vascular relaxation (12), and immunity (15). However, the inducible isoform of NOS (iNOS) appears to play a role in metastasis, especially in breast cancer (16). NOS and NOX products can interact, and this mechanism is a powerful regulatory modulator of their activity (17).

Leptin has been widely studied as one of many different adipokines that are modulated during obesity (18). Leptin is upregulated in obesity where it is involved in critical steps of cell homeostasis from cell growth (19) to metabolism (20) and energy production (21). A crosslink between ROS production and leptin signalling has been reported in several tissues including endothelium (22) and ovaries (23), and could be one of the signaling pathways activated through the leptin receptor OB-R in the presence of leptin (24). However, there is surprisingly little data on how leptin affects oxidative stress, especially in cancer (25). Several studies have investigated the impact of leptin on different steps in breast carcinogenesis (26) from cell proliferation $(27,28)$, inflammatory response (29) and modulation of the cell microenvironment (30) to cell signalling pathways $(27,31)$, but few of them have focused on intracellular ROS production $(32,33)$. 
ROS production is involved in the pathogenesis of both obesity (2) and cancer (3) while leptin plays a well-known role in breast carcinogenesis (34). Yet very few studies have assessed the ability of adipokines to modulate ROS production (35) via NOX and NOS enzymes in cancer cells.

Here we attempted to determine whether leptin, mimicking normal and obesity situations, modulates the activity and gene expression of NOS and NOX enzymes and whether ROS-producing enzymes are healthy-state or metastatic neoplastic-dependent. Regarding literature, plasma leptin concentrations were defined around 10 to $30 \mathrm{ng} / \mathrm{ml}$ and 50 to $150 \mathrm{ng} / \mathrm{ml}$ respectively for a lean and an obese adult woman (36). Thus, we chose leptin doses at $10 \mathrm{ng} / \mathrm{ml}$ for physiological and $100 \mathrm{ng} / \mathrm{ml}$ for obese conditions, which are also relevant to tissue concentrations (30). We used healthy (HMEC) and neoplastic (MCF-7 and MDA-MB-231) mammary epithelial cells that express the leptin receptor (Ob-R) (37) and are sensitive to leptin signalling (28) to assess and characterize cellular ROS production under leptin via different fluorescent probes (38). We then determined whether this ROS production could be due to NOX or NOS enzymes.

\section{Materials and methods}

Cell culture. Healthy human mammary epithelial cells (HMEC) obtained from 55-year-old Caucasian women (Lonza, Basel, Switzerland) were grown in complete MEBM medium supplemented with hydrocortisone $(0.5 \mu \mathrm{g} / \mathrm{m} 1)$, epithelial growth factor $(10 \mathrm{ng} / \mathrm{ml})$, insulin $(5 \mu \mathrm{g} / \mathrm{ml})$, gentamicin $(50 \mu \mathrm{g} / \mathrm{ml}) / \mathrm{amphotericin}-\mathrm{B}(50 \mathrm{ng} / \mathrm{ml})$ and bovine pituitary extract $(0.4 \%)$ as recommended by the manufacturer (Lonza). MCF-7 and MDA-MB-231 neoplastic human mammary epithelial cells obtained from 69- and 51-year-old Caucasian women, respectively (ATCC, Molsheim, France), were grown in RPMI-1640 medium (Biowest, Nuaillé, France) containing $10 \%$ fetal calf serum, L-glutamine ( $2 \mathrm{mM})$, penicillin (50 IU/ $\mathrm{ml})$ and streptomycin $(50 \mu \mathrm{g} / \mathrm{ml})$ (Sigma-Aldrich, SaintQuentin-Fallavier, France). Culture was carried out at $37^{\circ} \mathrm{C}$ in a humidified atmosphere with $5 \% \mathrm{CO}_{2}$ until passage 15 . For the experiments, the mammary epithelial cells were cultured at a density of 22,500 cells $/ \mathrm{cm}^{2}$.

Treatment with leptin. Mammary epithelial cells were synchronized in serum-free medium for $24 \mathrm{~h}$ before initiation of leptin treatment. Cells (HMEC, MCF7 and MDA-MB-231) were grown for $0-2 \mathrm{~h}$ in their media either with or without recombinant human leptin (R\&D Systems, Abingdon, UK) at physiological $(10 \mathrm{ng} / \mathrm{ml})$ or obese $(100 \mathrm{ng} / \mathrm{ml})$ concentrations. Cells were harvested after trypsinization. Total cell lysates were obtained by two successive thawing-freezing cycles in Tris $\mathrm{HCl} 25 \mathrm{mM}$ buffer $\mathrm{pH} 7.4$ containing Tween-20 $0.1 \%$ (Sigma-Aldrich), with 15 -sec periods in an ultra-sound bath, and then stored at $-80^{\circ} \mathrm{C}$ until analysis.

RNA isolation and reverse transcription. After treatment with leptin, total RNA was isolated from the epithelial cells by TRIzol ${ }^{\circledR}$ reagent (Invitrogen, Saint Aubin, France) according to the manufacturer's protocol, and quantified using a NanoDrop spectrophotometer (NanoDrop ${ }^{\circledR} 2000$, Thermo Scientific, Waltham, MA, USA). Reverse transcription was performed in a thermocycler (Mastercycler ${ }^{\circledR}$ gradient; Eppendorf, Montesson, France) on $1 \mu \mathrm{g}$ of total RNA for each condition using a highcapacity cDNA reverse transcription kit (Applied Biosystems, Saint Aubin, France) with random hexamer pdN6 primers.

Quantitative real-time PCR ( $q$-PCR). q-PCR was performed using SYBR ${ }^{\circledR}$ Green reagents according to the manufacturer's instructions on a StepOne system (Applied Biosystems). Each condition was assayed in triplicate. Relative quantification was obtained by the comparative $\mathrm{Cq}$ method, based on the formula $2^{-\Delta \Delta \mathrm{Cq}}$ (39). Expression levels were normalized to the housekeeping gene ( $\beta$-actin) for each time point and expressed as fold-change from the basal level corresponding to untreated cells at time 0 . Sequences and fragment sizes of the humanspecific primers used are reported in Table I.

Reactive oxygen species (ROS) production. ROS production was measured by fluorescence using a microplate reader (Fluoroscan Ascent Microplate Fluorometer ${ }^{\circledR}$, Thermo Scientific) for extracellular production and by flow cytometry for intracellular production (FC 500 MPL, Beckman Coulter, Villepinte, France). The probes used (FluoProbes ${ }^{\circledR}$, Interchim, Montluçon, France) are given in Table II. Total cellular ROS production was determined by dichlorofluorescein (DCF). Cytosolic superoxide anion $\left(\mathrm{O}_{2}^{-{ }^{-}}\right)$was assayed using dihydroethidine (DHE). Mitochondrial ROS production was assayed using dihydrorhodamine (DHR). Nitric oxide and peroxynitrite production was assayed using diaminofluorescein (DAF). Probe stock solutions (20 mM solution in DMSO) were stored under nitrogen at $-80^{\circ} \mathrm{C}$ until analysis. Probes were used at $2 \mu \mathrm{M}$ final concentration in cell media. Probe oxidation was measured at a wavelength of $488 \mathrm{~nm}$ for excitation and $520 \mathrm{~nm}$ for emission. Auto-oxidation of probe was subtracted. Results were normalized to the basal fluorescence signal without leptin and expressed in relative fluorescence units (RFU).

For extracellular production analysis, synchronized cells were incubated for $30 \mathrm{~min}$ in the dark at $37^{\circ} \mathrm{C}$ in their media with the appropriate probe $(2 \mu \mathrm{M})$. After adding leptin $(10$ or $100 \mathrm{ng} / \mathrm{ml}$ ) or medium (for control condition), cells were assayed for fluorescence every $10 \mathrm{~min}$ over a 120 -min window in the microplate reader.

For intracellular production analysis, synchronized cells were incubated in presence of leptin $(10$ or $100 \mathrm{ng} / \mathrm{ml})$ or medium (for control condition). After trypsinization, the cell suspension loaded with the appropriate probe $(2 \mu \mathrm{M})$ was incubated for $30 \mathrm{~min}$ in the dark at $37^{\circ} \mathrm{C}$ then, submitted to fluorescent flow cytometry analysis on a log scale for 10,000 events (cell counts).

Intracellular calcium influx. To assess the calcium-dependent signalling pathway in cell ROS production, calcium influx was measured by fluorescence on the microplate reader using the Fluo-3 calcium probe (Interchim) at $2 \mu \mathrm{M}$ as previously described (40). The effects of calcium channel blocking were measured in the presence of verapamil $(20 \mu \mathrm{M})$ (Sigma-Aldrich). After synchronization, the cells were incubated for $30 \mathrm{~min}$ in the dark at $37^{\circ} \mathrm{C}$ in the appropriate growth medium with verapamil before addition of Fluo-3 or dichlorofluorescein. After adding leptin (10 or $100 \mathrm{ng} / \mathrm{ml}$ ) or medium (for control condition) with or without verapamil, the cells 
Table I. Summary of PCR primers.

\begin{tabular}{|c|c|c|c|}
\hline Gene name & Accession no. & Primer sequences & Amplicon length (bp) \\
\hline NOX 1 & AJ_438989 & $\begin{array}{l}\text { F: 5'-TCG-ACC-ACC-AAT-ATT-CAC-CA-3' } \\
\text { R: 5'-TGG-CCT-TGT-CAA-AGT-TTA-AT-3' }\end{array}$ & 225 \\
\hline NOX 2 & NM_000397 & $\begin{array}{l}\text { F: 5'-AGA-GTT-CGA-AGA-CAA-CTG-GA-3' } \\
\text { R: 5'-CCT-CCT-TCA-GGG-TTC-TTT-AT-3' }\end{array}$ & 233 \\
\hline NOX 3 & NM_015718 & $\begin{array}{l}\text { F: 5'-CAA-ACA-CAA-CCA-CTG-AAT-TG-3' } \\
\text { R: 5'-TGT-TGT-GCA-GAG-AGA-GAC-TG-3' }\end{array}$ & 231 \\
\hline NOX 4 & NM_016931 & $\begin{array}{l}\text { F: 5'-CTT-TTG-GAA-GTC-CAT-TTG-AG-3' } \\
\text { R: 5'-ATC-AAG-CGG-CCC-CCT-TTT-TTC-AC-3' }\end{array}$ & 231 \\
\hline NOX 5 & NT_010194 & $\begin{array}{l}\text { F: 5'-CTC-ATT-CTC-ACA-CTC-CTC-GAC-AGC-3' } \\
\text { R: 5'-GTC-TGT-TCT-CTT-GCC-AAA-AC-3' }\end{array}$ & 238 \\
\hline DUOX1 & NP_059130 & $\begin{array}{l}\text { F: 5'-GCA-GGA-CAT-CAA-CCC-TGC-ACT-CTC-3' } \\
\text { R: 5'-CTG-CCA-TCT-ACC-ACA-CGG-ATC-TGC-3' }\end{array}$ & 348 \\
\hline DUOX2 & NP_054799 & $\begin{array}{l}\text { F: 5'-GAT-GGT-GAC-CGC-TAC-TGG-TT-3' } \\
\text { R: 5'-GCC-ACC-ACT-CCA-GAG-AGA-AG-3' }\end{array}$ & 303 \\
\hline iNOS & NP_000616 & $\begin{array}{l}\text { F: 5'-AGC-ATG-TAC-CCT-CGG-TTC-TG-3' } \\
\text { R: 5'-GGG-GAT-CTG-AAT-GTG-CTG-TT-3' }\end{array}$ & 250 \\
\hline eNOS & NP_000594 & $\begin{array}{l}\text { F: 5'-GAA-GAG-GAA-GGA-GTC-CAG-TAA-CA-3' } \\
\text { R: 5'-GGA-CTT-GCT-GCT-TTG-CAG-GTT-TTC-3' }\end{array}$ & 438 \\
\hline$\beta$-actin & NM_001101 & $\begin{array}{l}\text { F: 5'-TCG-TGC-GTG-ACA-TTA-AGG-AG-3' } \\
\text { R: 5'-AGC-ACT-GTG-TTG-GCG-TAC-AG-3' }\end{array}$ & 262 \\
\hline $18 \mathrm{~S}$ & NR_003286 & $\begin{array}{l}\text { F: 5'-GTC-TGT-GAT-GCC-CTT-AGA-3' } \\
\text { R: 5'-AGC-TTA-TGA-CCC-GCA-CTT-AC-3' }\end{array}$ & 177 \\
\hline
\end{tabular}

F, forward; R, reverse.

Table II. Fluorescence probes.

\begin{tabular}{|c|c|c|c|c|c|c|}
\hline \multirow[b]{2}{*}{ Species detected } & \multirow[b]{2}{*}{ Symbol } & \multicolumn{5}{|c|}{ Fluorescent probes } \\
\hline & & DCF & DHE & DHR & DAF & Fluo-3 \\
\hline Cytosolic superoxide anion & $\mathrm{O}_{2}^{\cdot-}$ & $\mathrm{X}$ & $\mathrm{X}$ & & & \\
\hline Mitochondrial superoxide anion & $\mathrm{O}_{2}^{\cdot-}$ & $\mathrm{X}$ & & $\mathrm{X}$ & & \\
\hline Hydrogen peroxide & $\mathrm{H}_{2} \mathrm{O}_{2}$ & $\mathrm{X}$ & & $\mathrm{X}$ & & \\
\hline Hydroxyl radical & $\mathrm{HO}$ & $\mathrm{X}$ & & & & \\
\hline Nitric oxide & NO• & $\mathrm{X}$ & & & $\mathrm{X}$ & \\
\hline Peroxynitrite & $\mathrm{ONOO}^{-}$ & $\mathrm{X}$ & & & $\mathrm{X}$ & \\
\hline Calcium & $\mathrm{Ca}^{2+}$ & & & & & $\mathrm{X}$ \\
\hline
\end{tabular}

were assayed for fluorescence every 10 min over a 120 -min window. Probe oxidation was measured at a wavelength of $488 \mathrm{~nm}$ for excitation and $520 \mathrm{~nm}$ for emission. Results were expressed in relative fluorescence units (RFU).
NOX catalytic activity. NOX catalytic activity was measured by fluorescence using a microplate reader (Fluoroscan Ascent Microplate Fluorometer, Thermo Scientific) in presence of dichlorofluorescein (DCF) (Interchim). 

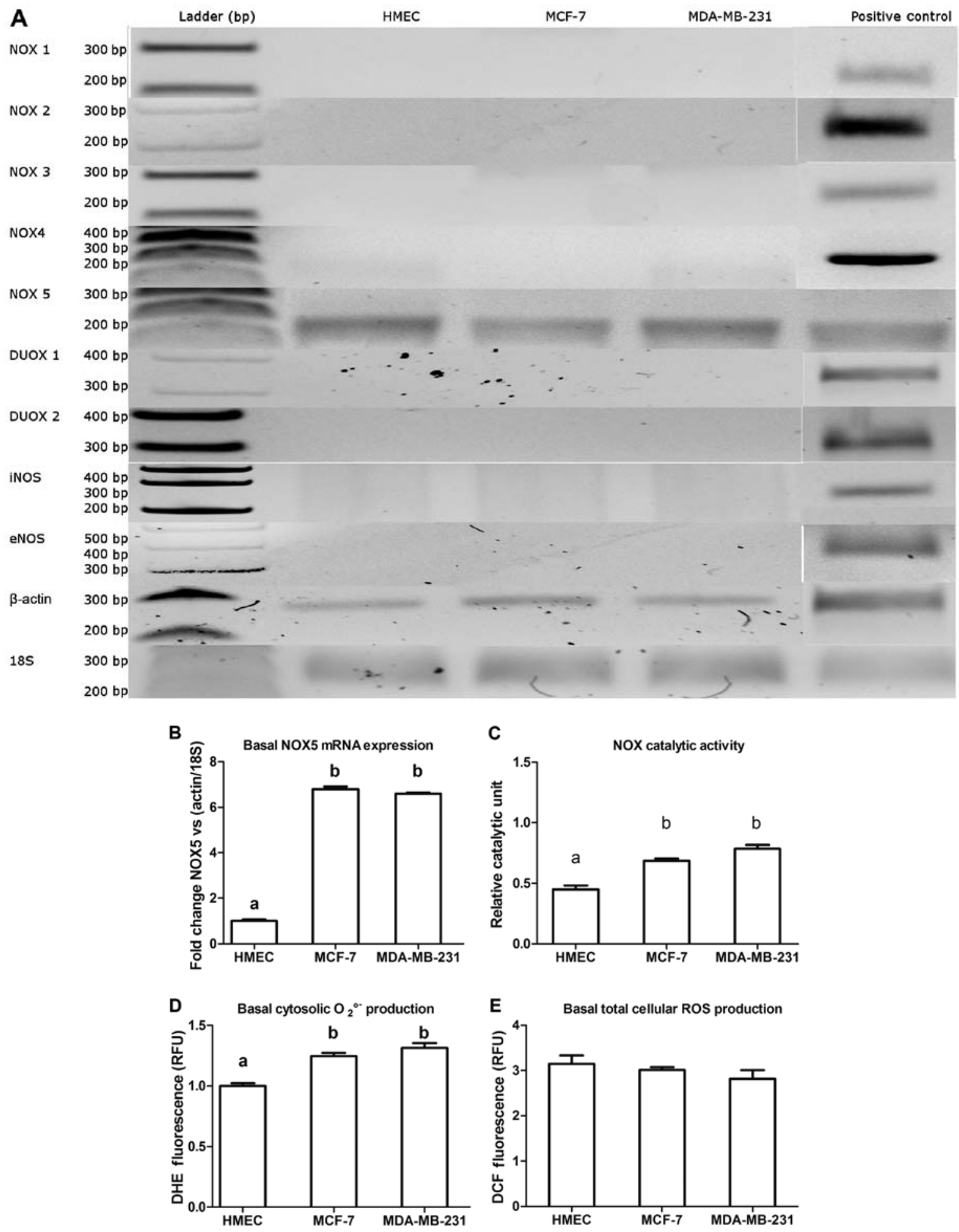

Figure 1. Basal ROS production, mRNA expression and catalytic activity of ROS production enzymes in human mammary epithelial cells. (A) mRNA expression of ROS production systems: electrophoresis of amplicons for NOX1, NOX2, NOX4, NOX5, DUOX1, DUOX2, iNOS, eNOS and actin in human mammary epithelial cells. (B) Basal expression by q-PCR of NOX5 in human mammary epithelial cells. (C) Basal catalytic activity of NOX in human mammary epithelial cells. (D) Basal cytosolic superoxide anion production (DHE) in human mammary epithelial cells. (E) Basal total cellular ROS production (DCF) in human mammary epithelial cells. Values are expressed as means \pm standard deviation $(n=6)$. Between-group comparisons were performed by one-way ANOVA followed by a Bonferroni multiple comparison test. Level of significance was set at 0.05 . Statistical significance between groups is indicated by different letters $(a \neq b, p<0.05)$.

Briefly, for experiments on the microplate reader: cells were incubated in the dark at $37^{\circ} \mathrm{C}$ in the reagent buffer (100 mM TrisHCl, $2 \mathrm{mM} \mathrm{MgCl} 2,0.5 \%$ Tween-20, $100 \mathrm{mM}$ $\mathrm{NADPH}, 10 \mu \mathrm{M}$ DCF, pH 7.4) (Sigma-Aldrich) in the presence or not of leptin at 10 or $100 \mathrm{ng} / \mathrm{ml}$. Plates were assayed for fluorescence every $60 \mathrm{sec}$ over a 10 -min window. Stimulation of the fluorescent signal was obtained by the addition of calcium chloride $(2 \mathrm{mM})$ in the reagent buffer. 

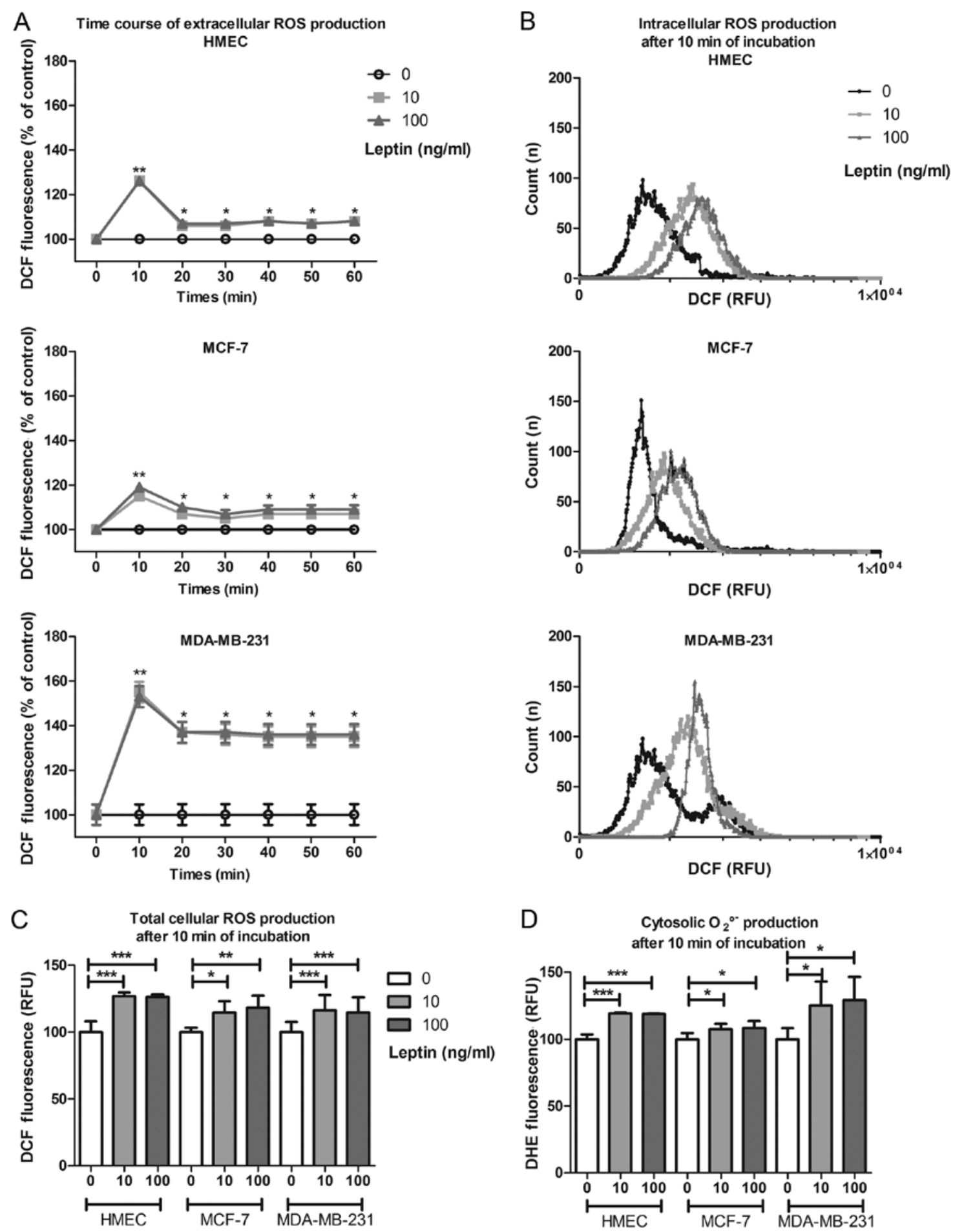

Figure 2. ROS production under leptin in healthy or neoplastic human mammary epithelial cells. (A) Time-course of extracellular ROS production (DCF) in HMEC, MCF-7 and MDA-MD-231. (B) Cytogram of total intracellular ROS production (DCF) in a representative experiment in HMEC, MCF-7 and MDAMD-231 after $10 \mathrm{~min}$ of incubation with leptin. (C) Total cellular ROS production at $10 \mathrm{~min}$ (DCF). (D) Cytosolic superoxide anion production at 10 min (DHE). Values are expressed as means \pm standard deviation ( $\mathrm{n}=6$ for $\mathrm{A}, \mathrm{C}$ and $\mathrm{D}$ ). Between-group comparisons were performed by one-way ANOVA followed by a Bonferroni multiple comparison test. Level of significance was set at 0.05 . Statistical significance between times or leptin concentrations is indicated by ${ }^{*} \mathrm{p}<0.05,{ }^{* *} \mathrm{p}<0.01$ and ${ }^{* * *} \mathrm{p}<0.001$.

NOX inhibition was assayed by the addition of diphenyliodonium (DPI) $(40 \mu \mathrm{M})$ to inhibit FAD enzymes or apocynin (ApoC) $(40 \mu \mathrm{M})$ to inhibit NOX 1, 2 and 4 (Sigma-Aldrich), as previously described (41). Results were expressed in relative catalytic units normalized to the protein content of the cell.
NOX5 silencing. To confirm the involvement of NOX5 in ROS production, its expression was inhibited via siRNA. We used 21-nucleotide double-stranded siRNAs (5 nM) (Qiagen HP genome wide siRNA databank, forward 5'-GCC CUA UUU GAC UCC GAU ATT-3', reverse 5'-UAU CGG AGU CAA AUA GGG CAA-3') targeting the NOX5 mRNA sequence. 
Non-silencing RNA (5 $\mathrm{nM}$ ) was used as negative siRNA control (scrambled siRNA).

The cells were siRNA-transfected as per the manufacturer's protocol (Qiagen, Courtaboeuf, France). Briefly, $22,500 / \mathrm{cm}^{2}$ cells were cultured in 6 -well plates. After incubation with siRNA for $1 \mathrm{~h}$, the wells were completed with the serum-free medium for $24 \mathrm{~h}$. Synchronized cells were assayed for ROS production by fluorescence using a microplate reader for $120 \mathrm{~min}$ as described above, either with or without 10 or $100 \mathrm{ng} / \mathrm{ml}$ recombinant human leptin. Cells were then harvested and quantitative RT-PCR was performed to compare NOX 5 mRNA silencing in the presence and absence of siRNA.

Statistical analysis. Each experiment was performed in triplicate and the average value was treated as a single data point. Statistical analyses were performed using GraphPad Prism5 (GraphPad Software, Inc., La Jolla, CA, USA). Data are expressed as means \pm standard deviation. Values for fluorescence measurements are expressed as a ratio of the control at baseline. Between-group comparisons were performed by one-way ANOVA followed by a Bonferroni multiple comparisons test. Level of significance was set at 0.05 . Significance is indicated by different subscript letters or flagged as $\mathrm{p}<0.05$, $\mathrm{p}<0.01$ and $\mathrm{p}<0.001$.

\section{Results}

Basal expression of ROS-producing enzymes and basal ROS production. ROS-producing enzymes of mammary epithelial cells were characterized in our culture cell conditions without leptin by q-PCR using previously-described primers (Table I) $(42,43)$. Of the different ROS-producing systems studied, i.e. NADPH oxidase (NOX) isoenzymes 1, 2, 4 and 5, dual oxidase (DUOX) isoenzymes 1 and 2, and the endothelial and inducible nitric oxide synthase isoforms (eNOS and iNOS), only NADPH oxidase 5 (NOX5) was expressed in our cell models (Fig. 1A). NOX5 mRNA expression was 6-fold higher in neoplastic cells than in healthy cells ( $p<0.05$, Fig. 1B).

Relative catalytic activity assayed by fluorescence in presence of NADPH and calcium showed similar profiles but was higher in neoplastic cells than HMEC ( $<<0.05$, Fig. 1C). This observation was related to the difference in NOX 5 expression. However, the basal cytosolic superoxide anion production was higher in neoplastic cells than in healthy cells $(\mathrm{p}<0.05$, Fig. 1D). Basal total cellular ROS production (without leptin) assayed with DCF was similar in the HMEC and neoplastic cell models (Fig. 1E).

Leptin-induced ROS production in human mammary epithelial cell lines. The time-course of total cellular ROS production (DCF) in the culture medium in the presence of leptin showed an increase at $10 \mathrm{~min}$, irrespective of cell model or leptin dose, $(126 \pm 4 \%, 115 \pm 2 \%$ and $155 \pm 19 \%$ of basal production for HMEC, MCF-7 and MDA-MB-231, respectively; $\mathrm{p}<0.05$, Fig. 2A). This short-term increase was followed by mid-term production for at least $1 \mathrm{~h}$ at $108 \%$ for HMEC and MCF-7 and at $135 \%$ for MDA-MB-231. This same increase in ROS production was confirmed by flow cytometry in each cell type (Fig. 2B). In presence of leptin, and whatever the cell model, total cellular ROS production significantly increased at $10 \mathrm{~min}$
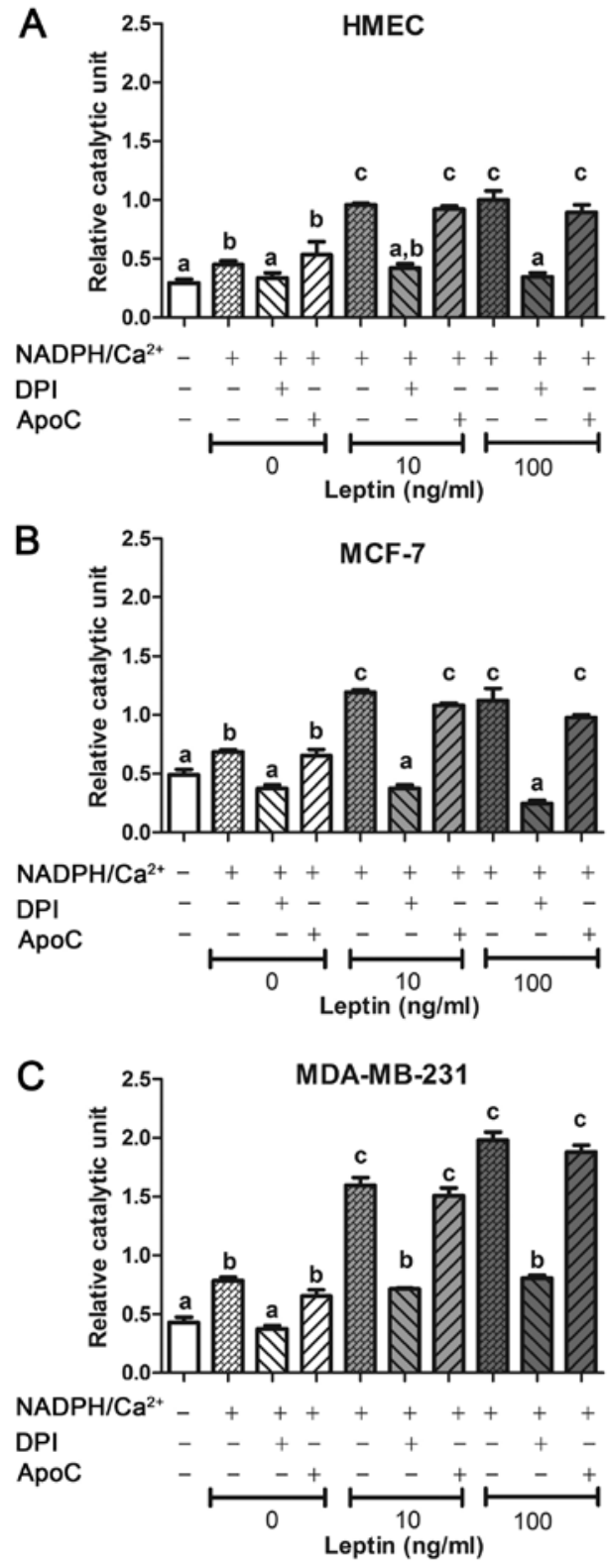

Figure 3. Inhibition of catalytic activity of NOX in presence of leptin (10 and $100 \mathrm{ng} / \mathrm{ml}$ ). (A) HMEC, (B) MCF-7, (C) MDA-MB-231. NOX catalytic activity was assayed by fluorescence in presence of NADPH and calcium. NOX catalytic activity was inhibited using DPI and apocynin (both well-known NOX inhibitors). Values are expressed as means \pm standard deviation $(n=6)$. Between-group comparisons were performed by one-way ANOVA followed by a Bonferroni multiple comparison test. Level of significance was set at 0.05 . Statistical significance between groups is indicated by different letters $(a \neq b, p<0.05)$.

$(\mathrm{p}<0.05$, Fig. 2C) without any difference between the two concentrations used. Cytosolic superoxide anion production assayed by DHE increased at $10 \mathrm{~min}$ in the presence of leptin (119, 108 and $125 \%$ of basal production for HMEC, MCF-7 and MDA-MB-231, respectively; p<0.05, Fig. 2D).

NOX isoenzyme involvement evaluated by inhibition with DPI and ApoC. The putative implication of a NOX enzyme was assayed on cells in the presence of two well-known NOX inhibitors: DPI and ApoC (41). For each cell line, after incubation with leptin, DCF fluorescence signal increased in the presence of NADPH and calcium and was greater in neoplastic cells than 
A
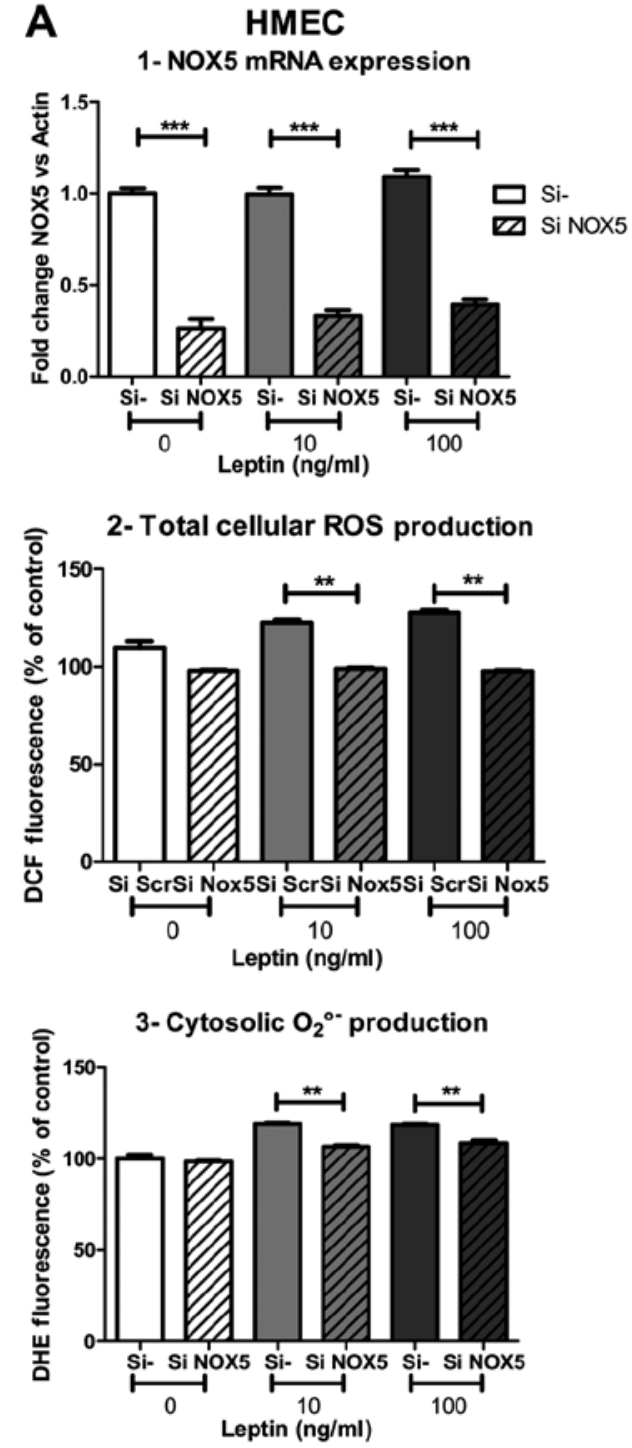

B
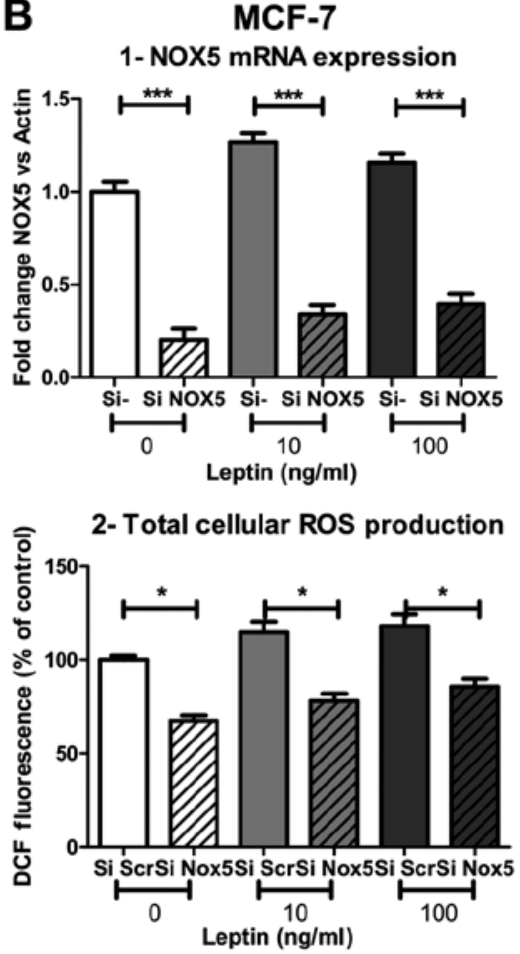

3- Cytosolic $\mathrm{O}_{2}{ }^{0 *}$ production

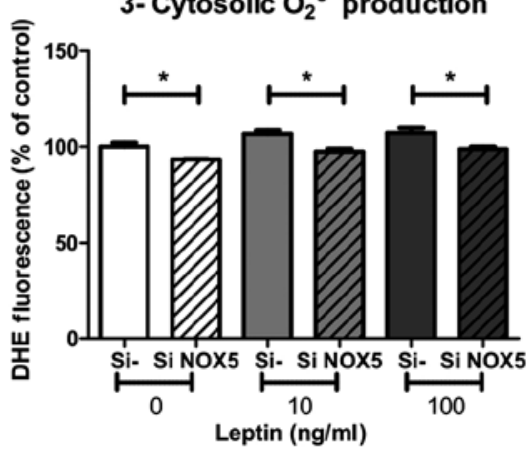

C

MDA-MB-231

1- NOX5 mRNA expression

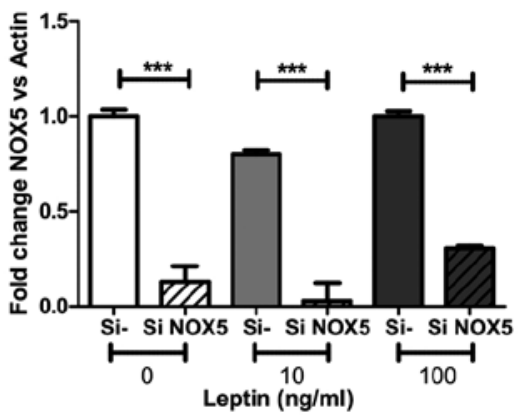

2- Total cellular ROS production
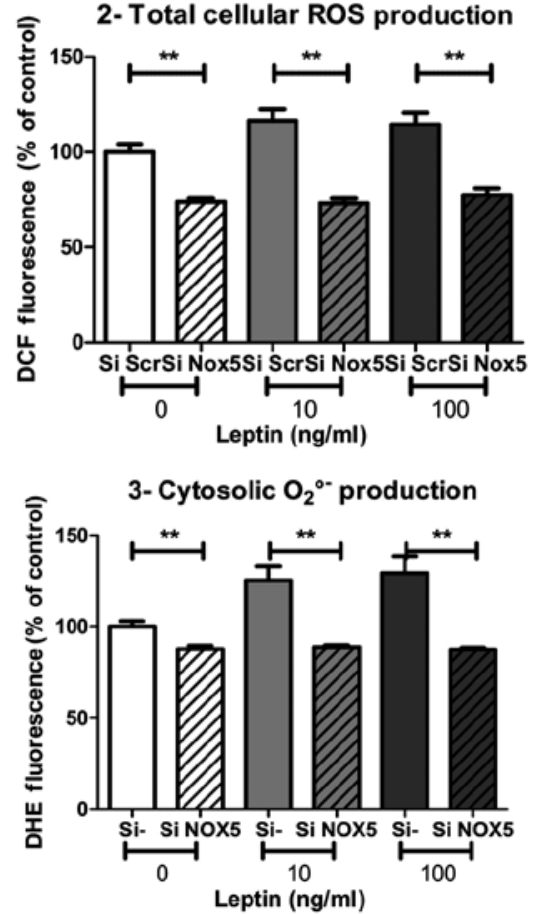

Figure 4. Involvement of the calcium-dependent NOX5 in ROS production in presence of leptin $(10 \mathrm{and} 100 \mathrm{ng} / \mathrm{ml})$. Effects of siRNA against NOX5 in terms of: 1) NOX5 mRNA expression, 2) total ROS production (DCF), 3) Cytosolic ROS production (DHE): (A) HMEC, (B) MCF-7, (C) MDA-MB-231. Values are expressed as means \pm standard deviation $(\mathrm{n}=6)$. Between-group comparisons were performed by one-way ANOVA followed by a Bonferroni multiple comparison test. Level of significance was set at 0.05 . Statistical significance between groups is indicated by ${ }^{*} \mathrm{p}<0.05,{ }^{* *} \mathrm{p}<0.01$ and ${ }^{* * *} \mathrm{p}<0.001$.

in HMEC (p<0.05, Fig. 3). In presence of NOX inhibitor DPI (which is efficient on all the isoenzymes as a FAD inhibitor), the fluorescence signal was totally inhibited only with DPI and was not different from the blank signal (Fig. 3). In the presence of NOX inhibitor ApoC (which is efficient on NOX1, NOX2 and NOX4) at $40 \mu \mathrm{M}$, relative catalytic activity showed no change in each cell line. DPI, but not ApoC, was able to inhibit this ROS production stimulated by NADPH and calcium. Taken together, these results suggest that the ROS-producing system was a FAD enzyme, which needs NADPH and calcium at the exclusion of NOX1, NOX2 or NOX4. NOX5 should be the isoenzyme present in these cells.

NOX5 involvement in ROS production under leptin was confirmed using siRNA. To better understand and confirm the involvement of NOX5 in ROS production, we used siRNA against NOX5 (siNOX5) to inhibit its expression. Twentyfour hours of NOX5 silencing potently inhibited NOX5 mRNA expression under basal conditions $(-74,-80$ and $-87 \%$ of mRNA expression in HMEC, MCF-7 and MDA-MB-231, respectively; $\mathrm{p}<0.001$, Fig. 4A1, B1 and $\mathrm{C1}$ ) and at both leptin concentrations. Surprisingly, despite the marked inhibition of mRNA expression, total cellular ROS production under basal conditions was not affected by the silencing in HMEC compared to neoplastic cells ( -33 and $-26 \%$ of inhibition in MCF-7 and MDA-MB-231, respectively; $\mathrm{p}<0.05$ and $\mathrm{p}<0.01$ Fig. 4A2, B2 and C2). Basal cytosolic superoxide anion production also seemed to be independent of NOX5, as only $25 \%$ of basal signal was inhibited in neoplastic cells $(\mathrm{p}<0.05$ and $\mathrm{p}<0.01$, respectively for MCF-7 and MDA-MB-231) and no change was observed in HMEC (Fig. 4A3, B3 and C3).

However, after NOX5 silencing, ROS production failed to increase whatever the leptin concentration and whatever the probe used for ROS detection. Total cellular ROS production under DCF decreased -22, -32 and $-37 \%$ in HMEC, MCF-7 and MDA-MB-231, respectively, with $10 \mathrm{ng} / \mathrm{ml}$ of leptin $(\mathrm{p}<0.01, \mathrm{p}<0.05, \mathrm{p}<0.01$, respectively; Fig. 4A2, B2 and C2). In the same experimental conditions, cytosolic superoxide anion 

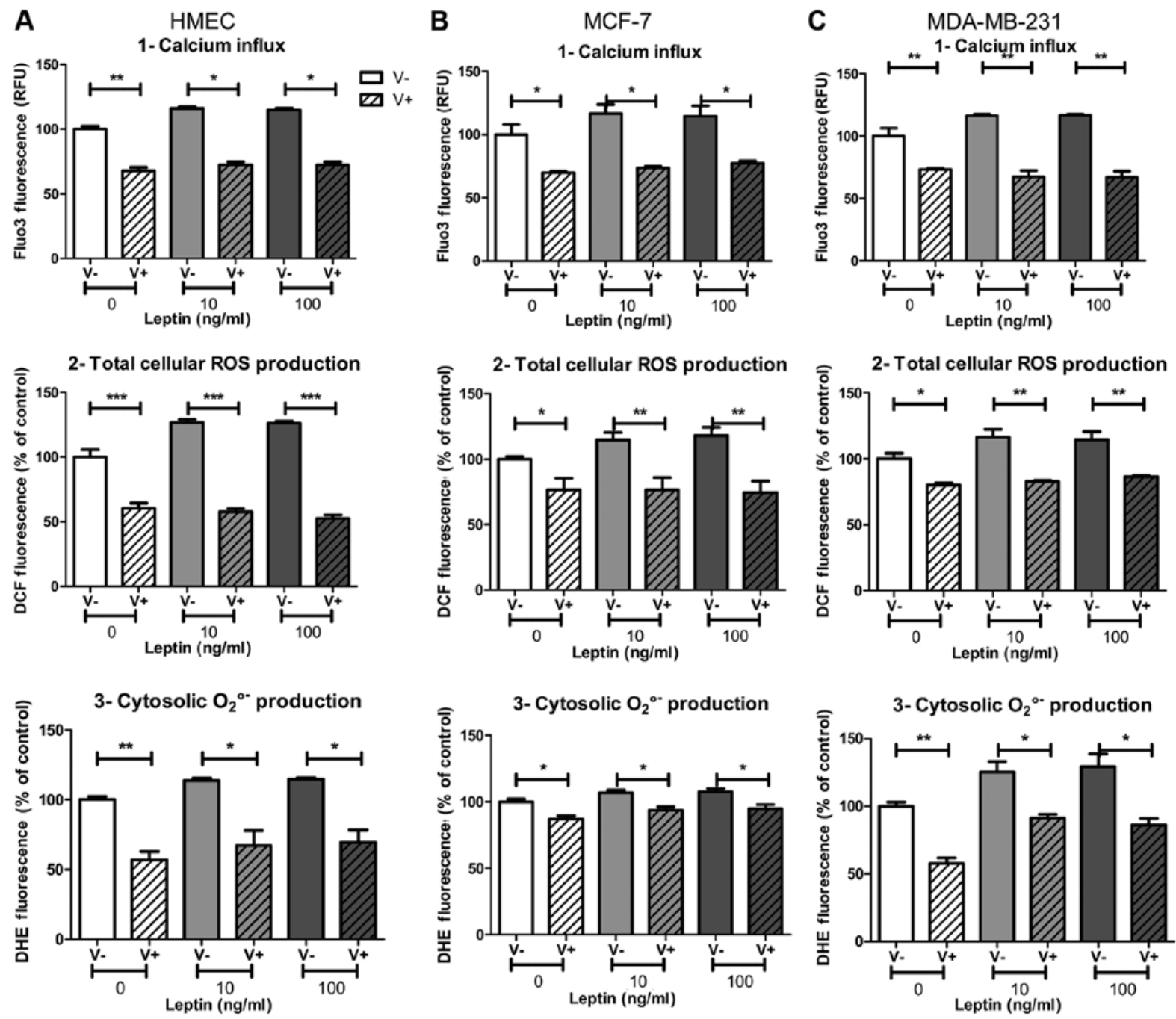

Figure 5. Involvement of the calcium influx in ROS production in presence of leptin (10 and $100 \mathrm{ng} / \mathrm{ml})$ : effect of calcium channel blocker. Effects of verapamil in terms of: 1) Calcium influx (Fluo3), 2) total ROS production (DCF), 3) Cytosolic ROS production (DHE): (A) HMEC, (B) MCF-7, (C) MDA-MB-231. Values are expressed as means \pm standard deviation $(\mathrm{n}=6)$. Between-group comparisons were performed by one-way ANOVA followed by a Bonferroni multiple comparison test. Level of significance was set at 0.05 . Statistical significance between groups is indicated by ${ }^{*} \mathrm{p}<0.05,{ }^{* *} \mathrm{p}<0.01$ and ${ }^{* * *} \mathrm{p}<0.001$.

production under DHE decreased $-10,-8$ and $-29 \%$ in HMEC, MCF-7 and MDA-MB-231, respectively, with $10 \mathrm{ng} / \mathrm{ml}$ of leptin ( $<<0.01, \mathrm{p}<0.05, \mathrm{p}<0.01$, respectively; Fig. 4A3, B3 and $\mathrm{C} 3$ ). In the three cell models, the increase in ROS production in the presence of leptin was completely suppressed by NOX5 siRNA treatment.

NOX5 activation by leptin was calcium flux-dependent. Calcium influx, which is a potent NOX5 activator (11), could be partly blocked by the calcium channel blocker verapamil. Whatever the cell model, leptin at both concentrations induced an increase in fluorescence of the calcium influx probe Fluo-3 $(+19,+23$ and $+20 \%$ in HMEC, MCF-7 and MDA-MB-231, respectively; $\mathrm{p}<0.05$, Fig. $5 \mathrm{~A} 1, \mathrm{~B} 1$ and $\mathrm{C} 1$ ) that was totally inhibited with verapamil. All the cell models were sensitive to verapamil, which is able to reduce calcium flux.

In the presence of verapamil, ROS production decreased in both basal and leptin conditions. However, basal ROS production seemed to be largely independent of calcium influx, since at least $45 \%$ of ROS production remained in the presence of the inhibitor verapamil. In the presence of leptin, verapamil decreased the signal measured for both total cellular ROS production and cytosolic superoxide anion production. In HMEC and MCF-7 cells, verapamil treatment decreased total ROS production and cytosolic superoxide anion production down to same level as basal conditions ( $<<0.01$, Fig. $5 \mathrm{~A} 2$, B2 and $\mathrm{p}<0.05$, Fig. 5A3, B3, respectively). In MDA-MB-231 cells, verapamil treatment totally suppressed total cellular ROS production under leptin to the same level as basal conditions ( $\mathrm{p}<0.01$, Fig. $5 \mathrm{C} 2$ ), whereas cytosolic superoxide anion production remained higher than without leptin $(\mathrm{p}<0.05$, Fig. 5C3).

Leptin downregulates NOX 5 mRNA expression. Gene expression of the ROS production enzymes was determined at 1 , 6 and $24 \mathrm{~h}$ by q-PCR after addition of 10 or $100 \mathrm{ng} / \mathrm{ml}$ of leptin. Only NOX5 mRNA expression showed a downregulation in the three cell models. In healthy HMEC, NOX5 expression was downregulated at 1,6 and $24 \mathrm{~h}(\mathrm{p}<0.001)$ whatever the leptin concentration, whereas neoplastic cells showed differences (Fig. 6A). In MCF-7 cells, NOX 5 expression was weakly downregulated at $6 \mathrm{~h}(\mathrm{p}<0.01)$ then increased at $24 \mathrm{~h}$ with 

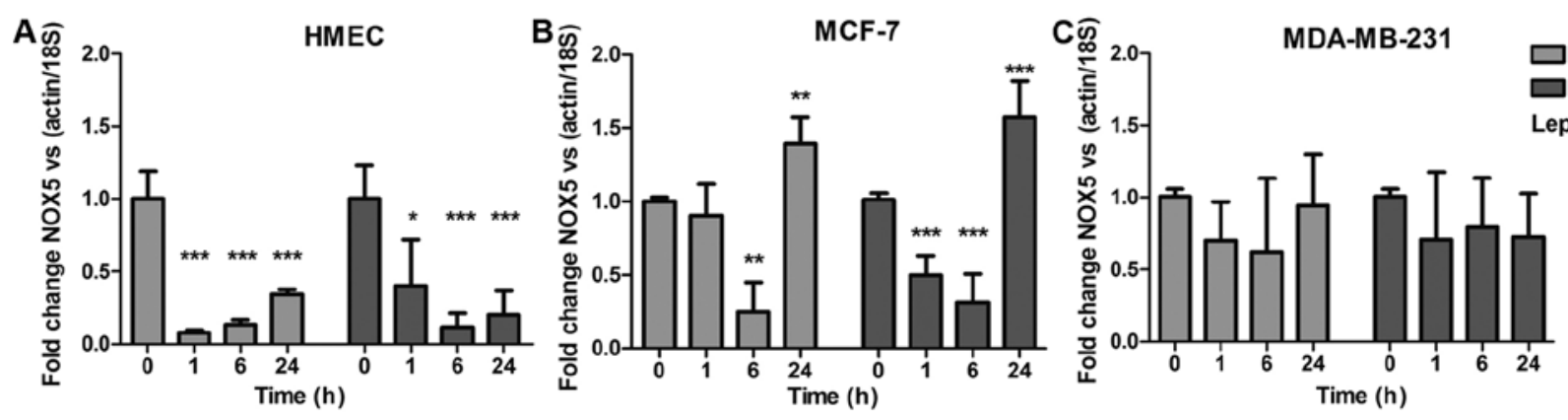

Figure 6. mRNA NOX5 expression in the presence of leptin (10 and $100 \mathrm{ng} / \mathrm{ml}$ ). Time-course of NOX5 mRNA expression for: (A) HMEC, (B) MCF-7, (C) MDA-MB-231. mRNA expression was determined by q-PCR at 0,1,6 and $24 \mathrm{~h}$ of leptin incubation. Values are expressed as means \pm standard deviation $(\mathrm{n}=6)$. Between-time comparisons were performed by one-way ANOVA followed by a Bonferroni multiple comparison test. Level of significance was set at 0.05 . Statistical significance between groups is indicated by ${ }^{*} \mathrm{p}<0.05,{ }^{* *} \mathrm{p}<0.01$ and ${ }^{* * *} \mathrm{p}<0.001$.

both leptin concentrations ( $<<0.01$; Fig. 6B). In MDA-MB231 cells, whatever the leptin concentration, NOX 5 expression showed no significant downregulation (Fig. 6C). None of the other NOX isoforms nor the NOS isoforms showed any detectable expression at any point in the 24-h experiment (data not shown).

\section{Discussion}

Leptin was able to modulate long-term ROS production after $24 \mathrm{~h}$ in mammary epithelial cells by modifying the mitochondrial function (33). However, mammary epithelial cells contain several NOX isoenzymes $(10,44)$ and there is very little data on whether leptin can modulate them. We thus focused our study on short-term ROS production and the potent role of NOX enzymes in the first hour of leptin stimulation at two concentrations $(10 \mathrm{ng} / \mathrm{ml}$ mimicking normal body mass index (BMI), $100 \mathrm{ng} / \mathrm{ml}$ mimicking obesity) on three mammary cell lines. These cell lines represented the major types of mammary epithelial cells i.e. HMEC for healthy cells, MCF-7 for estrogen sensitive neoplastic cells and MDA-MB-231 for metastatic triple-negative cells (31). Whatever the cell line, leptin briefly increased ROS production, which remained significantly higher than basal level for more than $1 \mathrm{~h}$. This study demonstrates for the first time that leptin is involved in short-term ROS production in epithelial mammary cells. The results are in agreement with previous work linking leptin to oxidative stress in other cell types such as endothelial cells, hepatic epithelial cells, cardiac myofibroblasts and ovarian cells $(22,23,25,35)$. However, leptin did not present a difference of effect despite our hypothesis on hyperleptinemia due to obesity. One of leptin regulation mechanism is the internalization of the complex leptin/receptor (26). In that case, cells became insensitive to leptin signal until the recycling of the receptor. As we used synchronized cells during a short time period, this mechanism could be pre-eminent in our in vitro experiments and could explain the lack of difference between leptin doses.

The NOX isoenzyme family is one of the most potent generators of ROS in cells (45). These enzymes are clearly involved in many pathological situations (46), especially carcinogenesis (47). Until recently, there was only scant data on the NOX isoenzyme family and the ROS production system in mammary epithelial cells (9), despite the important role of NOX isoforms as cellular signalling pathways (7). In our conditions, only NOX 5 mRNA presented significant expression levels in the three cell lines. NOX5 has been studied less than other NOX isoenzymes $(11,47)$ and its biological functions remain unclear, especially in cancer $(48,49)$. These data confirm the expression profile previously found in mammary tumor cell lines such as MCF-7 where NOX5 is the major NOX isoform expressed (9) and in breast tumors where NOX5 isoenzyme expression is positive in approximately $60 \%$ of tumors assessed (47). However, at variance with previous papers, the other NOX isoforms such as NOX2 (10), NOX3, or NOX4 (44), which are less expressed in breast cancer cells than NOX5, never presented significant mRNA expression during our short-time-window (less than $24 \mathrm{~h}$ ) conditions.

In order to confirm the implication of a NOX enzyme in ROS production, we first assayed two pharmacological NOX inhibitors (50): DPI, efficient on all NOX isoenzymes as well as other FAD enzymes and ApoC which interacts only with NOX1, 2 and 4 complexes (51). In our experiment, DPI but not ApoC was able to inhibit the short-term ROS production induced by leptin. These results argue for a FAD-dependent ROS production with NOX1, 2 and 4 apparently ruled out. Taken together, our findings suggest that NOX5 is likely the isoenzyme involved in this short-term response.

Secondly, we used siRNA against NOX5 to confirm its potent role. After $24 \mathrm{~h}$ of siNOX5 treatment, basal total cellular ROS production in absence of leptin partly decreased in the neoplastic cell lines but not in HMEC cells despite a significant decrease in NOX5 mRNA expression. Cytosolic superoxide anion production remained unchanged whatever the cell lines used. These results suggest that other potential ROS sources, such as mitochondrial oxidases $(33,44)$ or the respiratory chain (52), are involved in basal ROS production in these cells, as DCF was able to detect ROS coming from mitochondria. It could also be hypothesized that NOX5 protein turnover was slower than the decrease in mRNA expression, especially in HMEC cells, which presented slower growth. However, in presence of leptin, siNOX5 treatment abolished short-term ROS production whatever the cell line, both in terms of total cellular ROS and cytosolic superoxide anion. These results confirm that NOX5 is involved in part of the short-term leptin-induced ROS production.

The NOX5 complex features two domains for calcium binding which acts as the main regulator of its activity (11). 
In a final step of our experiment, we focused on the effect of calcium flux on short-term ROS production. In the presence of leptin, and as previously described $(53,54)$, we showed a calcium influx in the presence of Fluo-3 probe. Verapamil partly inhibited the calcium influx in the three cell lines, as Fluo-3 fluorescence only decreased by $30 \%$. In the presence of verapamil and leptin, total ROS production and cytosolic superoxide anion production decreased to under basal levels in both healthy HMEC and neoplastic MCF-7 cells. In MDA-MB-231 cells, only total cellular ROS production under leptin was suppressed down to basal levels by verapamil, whereas cytosolic superoxide anion production remained higher than in the basal condition without leptin. These data confirm that a calcium-dependent pathway is involved in short-term ROS production under leptin (53), which reinforces the idea that NOX5 plays a potent role in HMEC and MCF-7 cells but suggests another source of superoxide anion in MDA-MB-231 cells. However, as no other NOX isoenzyme was expressed in this short-time window, the identity of this other source remains unclear.

As the main long-term regulator of NOX5 is its mRNA expression level (49), we analyzed NOX5 mRNA expression after leptin stimulation in the three cell lines which showed different responses. In HMEC cells, NOX 5 mRNA expression decreased from 1 to $24 \mathrm{~h}$ at both concentrations of leptin, whereas the neoplastic cells did not show this downregulation pattern. After short decreases at 1 and $6 \mathrm{~h}$, in MCF-7 cells, NOX 5 expression increased higher than the basal level at $24 \mathrm{~h}$. In MDA-MB-231 cells, NOX5 expression was not modified during the $24 \mathrm{~h}$ time-window whatever the leptin concentration. In healthy cells, a feedback loop seems to exist when it is altered in MCF-7 cells, resulting in a higher mRNA expression at $24 \mathrm{~h}$. The metastasis of MDA-MB-231 cells lose this feedback loop for NOX 5 expression, that could be related to their more aggressive phenotype and their constitutive oxidative stress (55). The downregulation of NOX5 expression under leptin appears to be less effective in neoplastic cells and could be linked to the adverse effect of obesity in breast cancer risk $(26,29)$.

Herein, for the first time, leptin is demonstrated to induce short-term ROS production in both healthy and neoplastic human mammary epithelial cells for the two doses used (physio and obesity). This short-time ROS production under leptin appeared to be partly due to NOX5 as analysis of the mRNA expression levels of NOX-family members (FAD-dependent enzymes) showed a unique and significant NOX 5 expression in our conditions. Moreover, calcium influx inhibition by verapamil and FAD-dependent enzyme activity inhibition by DPI prevented ROS production that reinforce the NOX5 implication hypothesis. The main difference between the three mammary epithelial cell lines concerns the feedback loop of NOX5 mRNA expression which is less effective in neoplastic than in healthy cells. This lack of regulation in the neoplastic cells could be associated to the in-tumor major re-oxidative stress and related to the neoplastic processes in carcinogenesis (55). Taken together, our results point to the role for leptin in ROS production via NOX5 isoenzyme in mammary epithelial cells. This leptin ROS stimulation could be a potent actor in neoplastic cell signalling and could contribute to the increased risk of breast cancer associated to obesity $(32,48,56)$.

\section{Acknowledgements}

This work was supported by a PhD fellowship (Sinda Mahbouli) from the Conseil Régional d'Auvergne and the European research fund (FEDER). We thank Jacques Nunès for his valuable advice and expert knowledge on cell signaling and cancer cell biochemistry.

\section{References}

1. Basu S: Bioactive eicosanoids: Role of prostaglandin $F(2 \alpha)$ and $\mathrm{F}_{2}$-isoprostanes in inflammation and oxidative stress related pathology. Mol Cells 30: 383-391, 2010.

2. Fernández-Sánchez A, Madrigal-Santillán E, Bautista M, Esquivel-Soto J, Morales-González A, Esquivel-Chirino C, Durante-Montiel I, Sánchez-Rivera G, Valadez-Vega C and Morales-González JA: Inflammation, oxidative stress, and obesity. Int J Mol Sci 12: 3117-3132, 2011.

3. Valko M, Rhodes CJ, Moncol J, Izakovic M and Mazur M: Free radicals, metals and antioxidants in oxidative stress-induced cancer. Chem Biol Interact 160: 1-40, 2006.

4. Xia C, Meng Q, Liu L-Z, Rojanasakul Y, Wang X-R and Jiang B-H: Reactive oxygen species regulate angiogenesis and tumor growth through vascular endothelial growth factor. Cancer Res 67: 10823-10830, 2007.

5. Li J, Stouffs M, Serrander L, Banfi B, Bettiol E, Charnay Y, Steger K, Krause KH and Jaconi ME: The NADPH oxidase NOX4 drives cardiac differentiation: Role in regulating cardiac transcription factors and MAP kinase activation. Mol Biol Cell 17: 3978-3988, 2006.

6. Kovac S, Angelova PR, Holmström KM, Zhang Y, DinkovaKostova AT and Abramov AY: Nrf2 regulates ROS production by mitochondria and NADPH oxidase. Biochim Biophys Acta 1850: 794-801, 2015.

7. Jiang F, Zhang $Y$ and Dusting GJ: NADPH oxidase-mediated redox signaling: Roles in cellular stress response, stress tolerance, and tissue repair. Pharmacol Rev 63: 218-242, 2011.

8. Meitzler JL, Antony S, Wu Y, Juhasz A, Liu H, Jiang G, Lu J, Roy K and Doroshow JH: NADPH oxidases: A perspective on reactive oxygen species production in tumor biology. Antioxid Redox Signal 20: 2873-2889, 2014

9. Juhasz A, Ge Y, Markel S, Chiu A, Matsumoto L, van Balgooy J, Roy K and Doroshow JH: Expression of NADPH oxidase homologues and accessory genes in human cancer cell lines, tumours and adjacent normal tissues. Free Radic Res 43: 523-532, 2009.

10. Rao Malla R, Raghu $H$ and Rao JS: Regulation of NADPH oxidase (Nox2) by lipid rafts in breast carcinoma cells. Int $\mathbf{J}$ Oncol 37: 1483-1493, 2010.

11. Bedard K, Jaquet V and Krause K-H: NOX5: From basic biology to signaling and disease. Free Radic Biol Med 52: 725-734, 2012 .

12. Ziche M, Morbidelli L, Choudhuri R, Zhang HT, Donnini S, Granger HJ and Bicknell R: Nitric oxide synthase lies downstream from vascular endothelial growth factor-induced but not basic fibroblast growth factor-induced angiogenesis. J Clin Invest 99: 2625-2634, 1997.

13. Mattila JT and Thomas AC: Nitric oxide synthase: Non-canonical expression patterns. Front Immunol 5: 478, 2014.

14. Lander HM, Jacovina AT, Davis RJ and Tauras JM: Differential activation of mitogen-activated protein kinases by nitric oxiderelated species. J Biol Chem 271: 19705-19709, 1996.

15. Alblas J, Honing H, de Lavalette CR, Brown MH, Dijkstra CD and van den Berg TK: Signal regulatory protein alpha ligation induces macrophage nitric oxide production through JAK/STATand phosphatidylinositol 3-kinase/Rac1/NAPDH oxidase/ $\mathrm{H}_{2} \mathrm{O}_{2}$-dependent pathways. Mol Cell Biol 25: 7181-7192, 2005.

16. Ranganathan S, Krishnan A and Sivasithambaram ND: Significance of twist and iNOS expression in human breast carcinoma. Mol Cell Biochem 412: 41-47, 2016.

17. Delledonne M, Zeier J, Marocco A and Lamb C: Signal interactions between nitric oxide and reactive oxygen intermediates in the plant hypersensitive disease resistance response. Proc Natl Acad Sci USA 98: 13454-13459, 2001.

18. Sáinz N, Barrenetxe J, Moreno-Aliaga MJ and Martínez JA: Leptin resistance and diet-induced obesity: Central and peripheral actions of leptin. Metabolism 64: 35-46, 2015. 
19. Garonna E, Botham KM, Birdsey GM, Randi AM, Gonzalez-Perez RR and Wheeler-Jones CPD: Vascular endothelial growth factor receptor-2 couples cyclo-oxygenase-2 with pro-angiogenic actions of leptin on human endothelial cells. PLoS One 6: e18823, 2011.

20. Ehrhardt RA, Foskolos A, Giesy SL, Wesolowski SR, Krumm CS Butler WR, Quirk SM, Waldron MR and Boisclair YR: Increased plasma leptin attenuates adaptive metabolism in early lactating dairy cows. J Endocrinol 229: 145-157, 2016.

21. Park HK and Ahima RS: Physiology of leptin: energy homeostasis, neuroendocrine function and metabolism. Metabolism 64: 24-34, 2015.

22. Bouloumie A, Marumo T, Lafontan M and Busse R: Leptin induces oxidative stress in human endothelial cells. FASEB J 13 : 1231-1238, 1999.

23. Bilbao MG, Di Yorio MP, Galarza RA, Varone CL and Faletti AG: Regulation of the ovarian oxidative status by leptin during the ovulatory process in rats. Reproduction 149: 357-366, 2015

24. Bourgeais J, Gouilleux-Gruart V and Gouilleux F: Oxidative metabolism in cancer: A STAT affair? JAK-STAT 2: e25764, 2013.

25. Dattaroy D, Pourhoseini S, Das S, Alhasson F, Seth RK, Nagarkatti M, Michelotti GA, Diehl AM and Chatterjee S: Micro-RNA 21 inhibition of SMAD7 enhances fibrogenesis via leptin-mediated NADPH oxidase in experimental and human nonalcoholic steatohepatitis. Am J Physiol Gastrointest Liver Physiol 308: G298-G312, 2015.

26. Nalabolu MR, Palasamudram K and Jamil K: Adiponectin and leptin molecular actions and clinical significance in breast cancer. Int J Hematol Oncol Stem Cell Res 8: 31-40, 2014.

27. Naviglio S, Di Gesto D, Illiano F, Chiosi E, Giordano A, Illiano G and Spina A: Leptin potentiates antiproliferative action of cAMP elevation via protein kinase A down-regulation in breast cancer cells. J Cell Physiol 225: 801-809, 2010.

28. Dubois V, Jardé T, Delort L, Billard H, Bernard-Gallon D, Berger E, Geloen A, Vasson MP and Caldefie-Chezet F: Leptin induces a proliferative response in breast cancer cells but not in normal breast cells. Nutr Cancer 66: 645-655, 2014.

29. Vona-Davis L and Rose DP: The obesity-inflammation-eicosanoid axis in breast cancer. J Mammary Gland Biol Neoplasia 18 291-307, 2013.

30. Andò $\mathrm{S}$ and Catalano $\mathrm{S}$ : The multifactorial role of leptin in driving the breast cancer microenvironment. Nat Rev Endocrinol 8: 263-275, 2011

31. Guo S,Liu M, Wang G, Torroella-KouriMand Gonzalez-PerezRR: Oncogenic role and therapeutic target of leptin signaling in breast cancer and cancer stem cells. Biochim Biophys Acta 1825 207-222, 2012

32. Badid N, Ahmed FZB, Merzouk H, Belbraouet S, Mokhtari N Merzouk SA, Benhabib R, Hamzaoui D and Narce M: Oxidant/ antioxidant status, lipids and hormonal profile in overweight women with breast cancer. Pathol Oncol Res 16: 159-167, 2010.

33. Blanquer-Rosselló MM, Santandreu FM, Oliver J, Roca P and Valle A: Leptin modulates mitochondrial function, dynamics and biogenesis in MCF-7 cells. J Cell Biochem 116: 2039-2048, 2015.

34. Schmidt S, Monk JM, Robinson LE and Mourtzakis M: The integrative role of leptin, oestrogen and the insulin family in obesity-associated breast cancer: Potential effects of exercise. Obes Rev 16: 473-487, 2015.

35. Martínez-Martínez E, Jurado-López R, Valero-Muñoz M, Bartolomé MV, Ballesteros S, Luaces M, Briones AM, LópezAndrés N, Miana M and Cachofeiro V: Leptin induces cardiac fibrosis through galectin-3, mTOR and oxidative stress: Potential role in obesity. J Hypertens 32: 1104-1114, 2014.

36. Grossmann ME, Ray A, Nkhata KJ, Malakhov DA, Rogozina OP, Dogan S and Cleary MP: Obesity and breast cancer: Status of leptin and adiponectin in pathological processes. Cancer Metastasis Rev 29: 641-653, 2010.
37. Jardé T, Caldefie-Chézet F, Goncalves-Mendes N, Mishellany F, Buechler C, Penault-Llorca F and Vasson MP: Involvement of adiponectin and leptin in breast cancer: Clinical and in vitro studies. Endocr Relat Cancer 16: 1197-1210, 2009.

38. Woolley JF, Stanicka J and Cotter TG: Recent advances in reactive oxygen species measurement in biological systems. Trends Biochem Sci 38: 556-565, 2013.

39. Schefe JH, Lehmann KE, Buschmann IR, Unger T and FunkeKaiser H: Quantitative real-time RT-PCR data analysis: Current concepts and the novel 'gene expression's CT difference' formula. J Mol Med (Berl) 84: 901-910, 2006.

40. Minta A, Kao JP and Tsien RY: Fluorescent indicators for cytosolic calcium based on rhodamine and fluorescein chromophores. J Biol Chem 264: 8171-8178, 1989.

41. Rossary A, Arab K, Goudable J and Steghens JP: Fatty acids regulate NOX activity. Ann Biol Clin (Paris) 65: 33-40, 2007. (In French).

42. Rossary A, Arab K and Steghens J-P: Polyunsaturated fatty acids modulate NOX 4 anion superoxide production in human fibroblasts. Biochem J 406: 77-83, 2007.

43. Lamas B, Vergnaud-Gauduchon J, Goncalves-Mendes N, Perche O, Rossary A, Vasson M-P and Farges M-C: Altered functions of natural killer cells in response to L-Arginine availability. Cell Immunol 280: 182-190, 2012.

44. Graham KA, Kulawiec M, Owens KM, Li X, Desouki MM, Chandra D and Singh KK: NADPH oxidase 4 is an oncoprotein localized to mitochondria. Cancer Biol Ther 10: 223-231, 2010.

45. Li J-M and Shah AM: ROS generation by nonphagocytic NADPH oxidase: Potential relevance in diabetic nephropathy. J Am Soc Nephrol 14 (Suppl 3): S221-S226, 2003

46. Cave AC, Brewer AC, Narayanapanicker A, Ray R, Grieve DJ, Walker S and Shah AM: NADPH oxidases in cardiovascular health and disease. Antioxid Redox Signal 8: 691-728, 2006.

47. Antony S, Wu Y, Hewitt SM, Anver MR, Butcher D, Jiang G, Meitzler JL, Liu H, Juhasz A, Lu J, et al: Characterization of NADPH oxidase 5 expression in human tumors and tumor cell lines with a novel mouse monoclonal antibody. Free Radic Biol Med 65: 497-508, 2013.

48. Dho SH, Kim JY, Kwon E-S, Lim JC, Park SS and Kwon K-S: NOX5-L can stimulate proliferation and apoptosis depending on its levels and cellular context, determining cancer cell susceptibility to cisplatin. Oncotarget 6: 39235-39246, 2015.

49. Chen F, Wang Y, Barman S and Fulton DJR: Enzymatic regulation and functional relevance of NOX5. Curr Pharm Des 21: 5999-6008, 2015.

50. Aldieri E, Riganti C, Polimeni M, Gazzano E, Lussiana C, Campia I and Ghigo D: Classical inhibitors of NOX NAD $(\mathrm{P}) \mathrm{H}$ oxidases are not specific. Curr Drug Metab 9: 686-696, 2008.

51. Petrônio MS, Zeraik ML, Fonseca LM and Ximenes VF: Apocynin: Chemical and biophysical properties of a NADPH oxidase inhibitor. Molecules 18: 2821-2839, 2013

52. Ameri K, Jahangiri A, Rajah AM, Tormos KV, Nagarajan R, Pekmezci M, Nguyen V, Wheeler ML, Murphy MP, Sanders TA, et al: HIGD1 A regulates oxygen consumption, ROS production, and AMPK activity during glucose deprivation to modulate cell survival and tumor growth. Cell Rep 10: 891-899, 2015.

53. Martín-Romero C and Sánchez-Margalet V: Human leptin activates PI3K and MAPK pathways in human peripheral blood mononuclear cells: Possible role of Sam68. Cell Immunol 212: 83-91, 2001.

54. Trachootham D, Lu W, Ogasawara MA, Nilsa RD and Huang P: Redox regulation of cell survival. Antioxid Redox Signal 10: 1343-1374, 2008

55. Nourazarian AR, Kangari P and Salmaninejad A: Roles of oxidative stress in the development and progression of breast cancer. Asian Pac J Cancer Prev 15: 4745-4751, 2014.

56. Chen F, Yu Y, Haigh S, Johnson J, Lucas R, Stepp DW and Fulton DJR: Regulation of NADPH oxidase 5 by protein kinase C isoforms. PLoS One 9: e88405, 2014. 